\title{
Penyuluhan Tentang Cara Pembuatan Media Biopori Untuk Pengendalian Banjir di Perumahan BTN Pengsong Indah Desa Perampuan Kecamatan Labuapi Kabupaten Lombok Barat
}

\author{
I Dewa Gede Jaya Negara, Hasyim, Ratna Yuniarti , Ngudiono, I W Sugiartha
}

Jurusan Teknik Sipil, Fakultas Teknik, Universitas Mataram, Mataram, Indonesia

Alamat korespondensi : jayanegara69@gmail.com

\begin{abstract}
ABSTRAK
Perumahan BTN Pengsong Indah merupakan pakan kawasan perumahan yang memliki topografi yang rendah, dimana jalan raya berelevasi lebih tinggi dari lokasi perumahan warga, yang sangat potensial mangalami genangan atau banjir saat musim hujan. Banjir tersebut terbukti terjadi pada tanggal 10 Januari tahun 2009 yang merendam perumahan warga selama 1,5 hari. Solusinya ditawarkan untuk mengatasi permasalahan tersebut adalah dengan memberikan menyuluh bio pori pada masyarakat, untuk mereduksi banjir dan melakukan pembuatan dan pemasangan bio pori, disekitar perumahan warga BTN sebagai media resapan yang bisa dicontoh.

Kegiatan penyuluhan ini akan dilakukan dengan beberapa tahapan kegiatan mulai dari tinjauan lokasi pengabdian, identifikasi masalah banjir dan drainase, koordinasi dengan pemuka masyarakat dan ketua RT maupun ketua kelompok warga, sampai penyiapan material program aksi dan koordinasi jadwal waktu kegiatan penyuluhan dengan warga BTN tersebut. Pada tahap penyuluhan materi tentang pentingnya peresapan air ke dalam tanah dengan bio pori, bahan yang dipakai, cara memasangnya guna pengendalian limpasan hujan akan diberikan tim pengabdian.

Berdasarkan kondisi yang ada, pelaksanaan penyuluhan hanya dapat dilakukan dengan media pamphlet untuk penyampaian teori tentang biopori, sedangkan untuk mengadakan tanya jawab dilakukan saat pemasangan biopori di rumah warga. Dalam kondisi Covid-19, krumunan warga dalam jumlah besar sangat dihindari, sehingga kegiatan ini dilakukan beberapa kali pertumuan secara terpisah untuk dapat mengedukasi warga setempat. Intinya pemasangan bio pori dapat dilakukan pada 7 lokasi dikawasan BTN Pengsong Indah dan berjalan lancar. Hasil evaluasi menunjukkan masyarakat sangat tertarik dengan materi saat penyuluhan karena telah diketahui dapat mereduksi genangan disekitar permukiman pada musim hujan.
\end{abstract}

Keywords : reduksi, banjir, media resapan

\section{PENDAHULUAN}

Perumahan BTN Pengsong Indah merupakan perumahan yang terbangun pada lahan yang dahulunya merupakan lahan persawahan, dengan kondisi topografi lahan yang sangat rendah. Lokasi tersebut merupakan daerah langganan banjir setiap musim hujan, dan kadangkadang memperoleh banjir kiriman dari daerah bagian hulunya. Dengan berkembangnya pembangunan di wilayah di kabupaten Lombok Barat terutama di bidang bina marga, sering kali dilakukan peninggian jalan raya sekitarnya oleh pemerintah sehingga mengakibatkan posisi lokasi perumahan tersebut menjadi semakin dalam. Hal tersebut memberi berdampak pada semakin kecilnya peluang lokasi tersebut bebas dari banjir, apalagi memang sejak lama telah sering terjadi banjir saat musim hujan diperumahan tersebut. Memperhatikan kondisi topografi perumahan tersebut yang elevasinya rendah dari jalan raya dan kebanyakan rumah warga masih merupakan rumah lantai 1 , maka potensi genangan atau mungkin banjir masih berpeluang besar akan terjadi di tempat tersebut. Terbukti pada tahun 2009 yaitu pada tanggal 10 Januari 2009, di perumahan tersebut telah terjadi banjir besar selama 1,5 hari dan merendam 
rumah $60 \mathrm{kk}$ dari warga. Dengan kondisi luas lahan yang terbatas maka untuk dapat mengatasi kejadian banjir tersebut dengan teknik Embung Lahan (Jaya Negara, et al., 2016) adalah tidak mungkin karena luas lahan yang dibutuhkan cukup luas dan tidak dapat dipenuhi oleh kondisi BTN tersebut. Untuk mengatasi hal di atas, perlu upaya agar peresapan air limpasan hujan dapat dilakukan pada luas yang terbatas sehingga kondisi yang ada sangat sesuai dengan kebutuhan peresapan hujan tersebut. Alternatif lainnya adalah dengan teknik bio pori, cara ini dapat dilakukan dengan luas lahan terbatas dan lebih fleksibel. Menurut Permanasari Eka., dkk (2018) dalam penelitiannya yang berjudul "Penyelamatan Air tanah dan Penanggulangan Sampah dengan teknik Bio pori dan Komposter di Pemukiman Kecil Di keluaraman Ciputata dan Ciputat Timur, telah memberikan ide untuk mengatasi permasalahan genangan yang terjadi di lokasi pengabdian. Hanya dengan bahan pipa 4" dan bor tangan digunakan membuat lubang pada tanah di pekarangan akan, dapat dilakukan peresapan air hujan tersebut dengan sederhana. Tetapi bagaimana caranya membuat teknik bio pori tersebut, maka warga BTN Pengsong Indah perlu diberi penyuluhan, agar dapat mengatasi masalah genangan atau banjir pada lingkungannya. Melalui penyuluhan warga akan mendapat wawasan tentang apa itu banjir dan bagaimana cara warga dapat mengatasinya secara swadaya. Hal tersebut menjadi penting, karena daerah tersebut berada pada posisi di bawah elevasi permukaan jalan dan di sekitar perumahan terdapat penggunungan yang sewaktu-waktu dapat memberikan limpasan banjir pada perumahan tersebut.Teknik biopori merupakan salah satu cara yang dapat digunakan menanggulangi limpasan yang terjadi setempat, karena kemampuannya terbatas dan dapat diaplikasi pada luas lahan yang terbatas. Penggunaan sumur resapan untuk lokasi dengan muka air tanah sangat tinggi seperti pada lokasi perumahan tersebut sangatlah tidak mungkin, sehingga pendekatan menggunakan biopori mungkin dapat membantu masyarakat di perumahan BTN Pengsong Indah mengatasi masalah limpasan air hujan dan mereduksi genang setempat. Untuk mengatasi permasalahan genangan dan banjir yang mungkin terjadi di perumahan BTN Pengsong Indah, sangat perlu dilakukan penyuluhan agar warga dapat mengetahui apa penyebabnya dan bagaimana cara mengatasinya secara teknis dan nonteknis dimasa-masa mendatang.

Manfaat yang akan dapat diberikan dari penyuluhan ini adalah adanya pemahaman masyarakat setempat tentang banjir, masalah-masalah yang menimbulkan banjir, sumbersumber yang memicu terjadinya banjir, cara mengatasi banjir secara swadaya dan non teknis dan cara-cara mengatasi banjir dengan teknis. Masyarakat akan tahu lebih banyak cara mengatasi banjir secara teknis yang dapat dilakukan secara swadaya yang telah dilakukan pada daerah lain seperti cara membuat bio pori. Bio pori dapat dibuat dari bahan yang murah dan mudah diperoleh atau dapat membuat dan di paasang secara swadaya pada tempat-tempat yang mungkin dilakukan, atau dapat memilih cara yang paling mungkin mengatasi banjir ditempat tersebut. Dengan Penyuluhan ini masyarakat perumahan BTN Pengsong Indah akan memperoleh pengetahuan yang lebih lengkap sehingga akan siap dalam menghadapi masalah banjir dimasa- masa mendatang. Singkatnya manfaat yang dapat masyarakat secara umum dapat diuraikan sebagai berikut dapat meningkatkan wawasan masyarakat di BTN tentang masalah genangan, masalah banjir, sumber-sumber banjir dan hubungannya dengan air tanah.Mendapat wawasan tentang cara-cara mengatasi banjir dilingkungan dengan elevasi yang rendah untuk antisipasinya menjelang musim hujan di BTN dan sekitar.Dapat mengetahui alternatif dan cara mereduksi terjadinya genangan yang mengarah pada terjadinya banjir dengan Teknik Bio Pori. Warga BTN akan dapat membuat Bio pori secara swadaya dimasa-masa mendatang.Meningkatkan pengetahuan masyarakat tentang resapan air ke dalam tanah sebagai reklamasi air tanah. 
Dengan banyaknya menfaat yang akan diperoleh warga BTN Pengsong Indah, maka penyuluhan ini memang sangat diperlukan warga untuk meningkatkan kewaspadaan warga dan karena lokasi sasaran merupakan daerah rawan banjir.

\section{METODELOGI KEGIATAN}

Metode yang digunakan melakukan kegiatan pengabdian ini adalah dengan penyuluhan dan pembuatan contoh biopori yang terdiri dari tahapan:

a. Koordinasi pengabdian. Dilakukan koordinasi dengan tim tentang lokasi kegiatan dan persiapan survey lokasi dan koordinasi dengan mitra.

b. Kegiatan survey lokasi dan identifikasi.Dilakukannya tinjauan lapangan untuk mengkomunikasikan kegiatan dengan pemuka masyarakat dan tokoh-tokoh masyarakat. Mendata kondisi lokasi BTN Pengsong Indah, melakukan pengecekan kondisi air tanah terhadap muka tanah sekitar, mendata kondisi topografi lokasi , jaringan drainase dan mendata kejadian-kejadian banjir/genangan pada setiap musim hujan.

c. Penyiapan fokus materi suluh.Dalam kegiatan ini fokus materi-materi suluh adalah tentang Biopori memanfaatkan sumberdaya tim yang ada dalam kondisi Covi-19, menentukan pola penyuluhan yang akan dilakukan.

d. Pembuatan pamplet sebagai media suluh. Pembuatan media biopori dengan pipa 4" untuk dipemasang sebagai contoh biopori disekitar permukiman warga.

e. Penentuan pelaksanaan kegiatan dan penentuan jadwal pelaksanaan.

Jadwal penyuluhan ditentukan berdasarkan kesediaan waktu tim penyuluh dan waktu masyarakat di BTN Pengsong Indah terkait dengan kondisi covid-19. Perlu singkronisasi waktu dan tempat di lokasi penyuluhan agar dapat menjadi pelaksanaan kegiatan dapat berjalan lancar.

\section{f. Pelaksanaan penyuluhan dan diskusi, tanya jawab}

Pembukaan penyuluhan dilakukan oleh ketua tim dan ketua kelompok warga BTN, yang menyampaikan materi maksud dan tujuan kegiatan dan permasalahan yang ingin disuluhkan ke peserta.

Metode penyuluhan dilakukan dengan pemberian pamplet kepada warga yang dilakukan oleh ketua tim penyuluh dan pemuka masyarakat. Pertanyaan-pertanyaan ada ditampung dan dibahas pada saat pembuatan media biopori di lapangan.

\section{HASIL DAN PEMBAHASAN}

Kegiatan awal pengabdian yang dilakukan adalah koordinasi dengan warga yang ada dilokasi BTN Pengsong Indah, untuk mengkomunikasikan kegiatan lapangan seperti tinjauan lapangan dan untuk mengetahui kondisi masyarakat pada kondisi Covid-19 jika penyuluhan dilakukan. Berdasarkan kesepakatan dengan pemuka masyarakat maka tim melakukan tinjauan lapangan seperti pada Gambar 1 

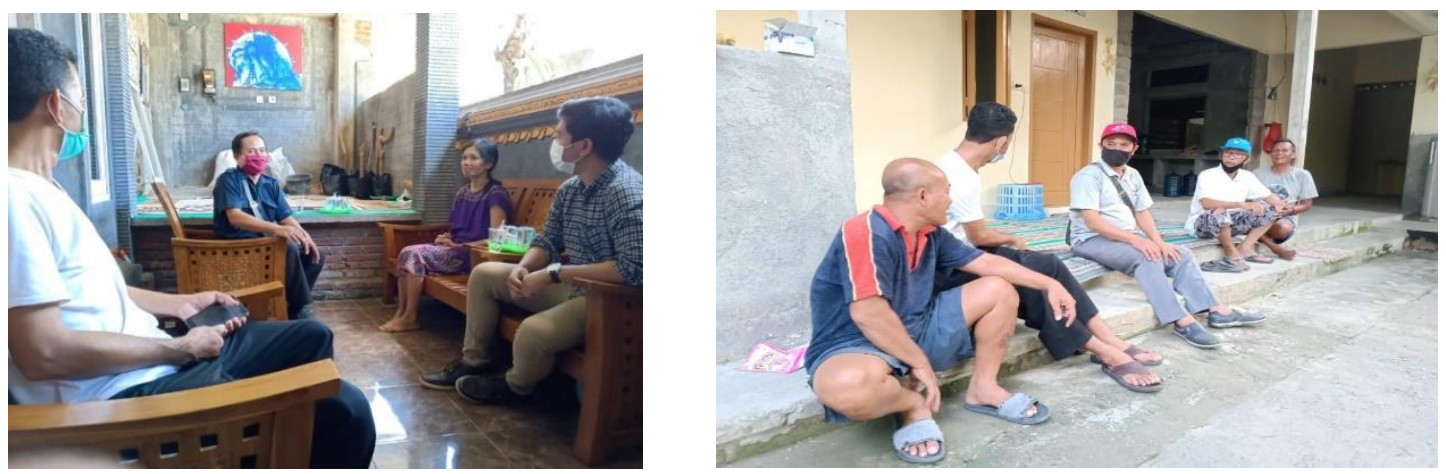

Gambar 1.Kegiatan Sosialisasi

Dalam tinjauan lapangan ini, tim mengali informasi lapangan yang terkait dengan masalah banjir yang pernah terjadi dan kondisi perumahan BTN ini disaat musim hujan. Berdasarkan fakta bahwa lokasi pengabdian merupakan daerah rawan banjir dan kondisi muka air tanahnya termasuk dangkal. Kegiatan tinjauan pada lokasi-lokasi rawan banjir ditunjukkan pada Gambar
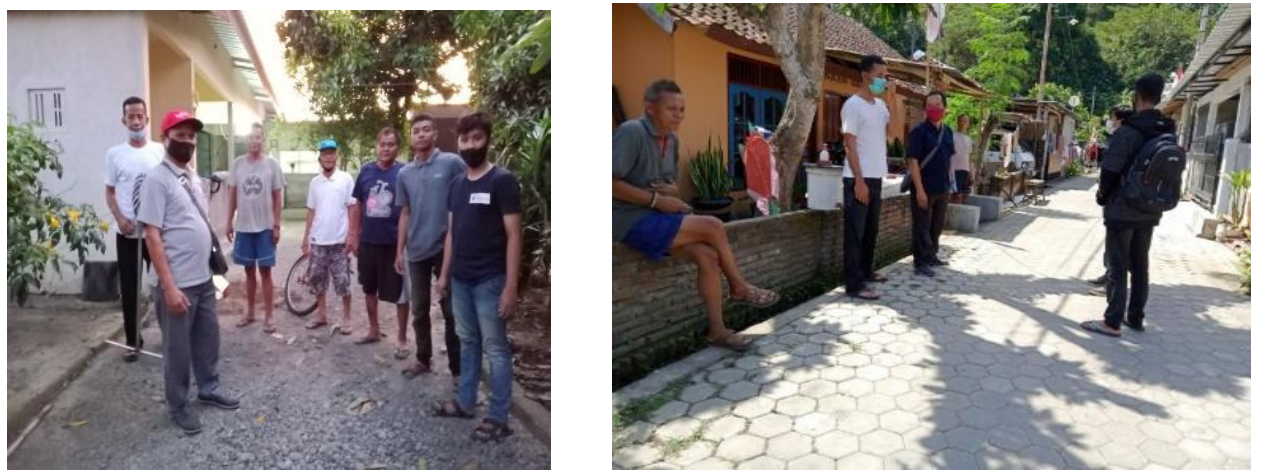

Gambar 2. Kegiatan Sosialisasi

\section{Persiapan Media Penyuluhan}

Media penyuluhan yang disiapkan tim adalah leaflet dan media biopori yang dilakukan penyiapan secara simultan, agar pengabdian dapat dilakukan secara sinergis. Sedangkan dalam rangka penyediaan media biopori yang dilakukan adalah penyiapan alat dan bahan penyuluhan berupa pipa pvc dan tutup, pembuatan media biopori dapai dilihat Gambar 3. Pipa pvc 4" yang sudah disiapkan kemudian dipotong menjadi beberapa bagian dengan panjang sekitar 1 $\mathrm{m}$. Pipa yang sudah dipotong dan diberi garis tanda untuk dibor, kemudian di bor dengan bor tangan dengan jarak lubang sekitar $10 \mathrm{~cm}$ dan dibuat pada 4 lajur sisi pipa. Kegiatan tersebut ditunjukkan pada gambar berikut.
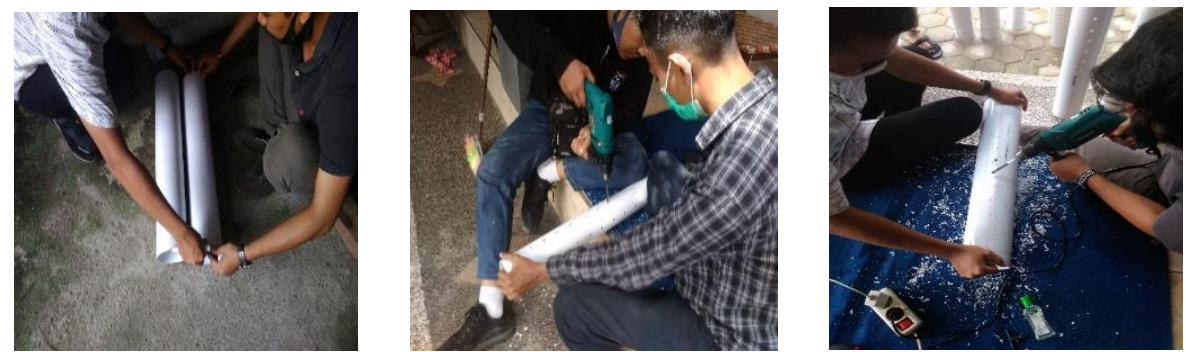

Gambar 3. Pembuatan media Biopori 
Untuk pipa yang sudah selesai di bor kemudian dibersihkan dari serbuk bekas bornya agar lubangnya bulat sempurna. Setelah bersih pipa yang sudah selesai dibor tersebut dikumpulkan dan disiapkan tutup pipanya dan diberi lubang dengan bor. Media biopori yang sudah siap dipasang kemudian dikumpulkan untuk persiapan pemasangan di BTN Pengsong Indah, seperti pada Gambar 4.
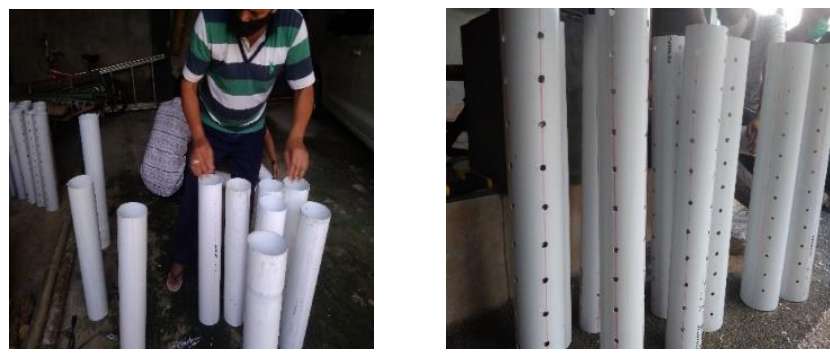

Gambar 4. Media Biopori Siap Dipasang

\section{Serah Terima Media Biopori dan Leaflet}

Sesuai hasil koordinasi dengan pemuka masyarakat dilokasi pengabdian, sebelum dilakukan pemasangan biopori di perumahan ini maka masyarakat perlu menerima media tersebut untuk kemudian dipasang di halaman rumah dan pekarangan yang dimiliki. Serah terima media biopori dibarengi dengan penyelarah leaflet penyuluhan ke warga agar dapat dibaca untuk menambah pengetahuan. Kegiatan serah terima material penyuluhan dapat dilihat pada Gambar 5

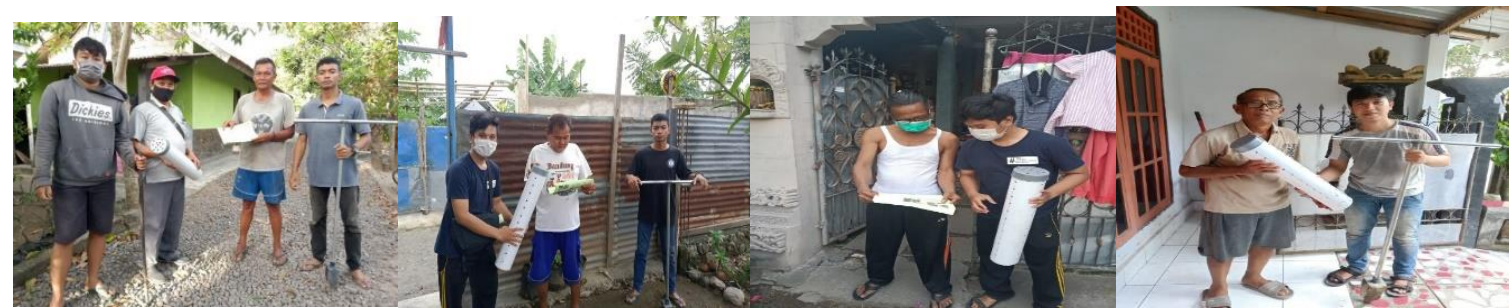

Gambar 5. Penyebaran Pamplet Pembuatan biopori pada warga BTN Pengsong Indah

\section{Pemasangan Contoh Biopori}

Pemasangan biopori dilokasi BTN Pengsong Indah dilakukan diberbagai kondisi lahan yang tersedia seperti pada halaman pekarangan yang belum diperkeras, pada halaman rumah yang sudah di paving atau disemen dan ada juga pada lahan pekarangan yang sudah dipasang keramik karena seluruh ruang telah diperkeras, sehingga pemasangan biopori disesuaikan seperti ditunjukkan pada Gambar 6 berikut.
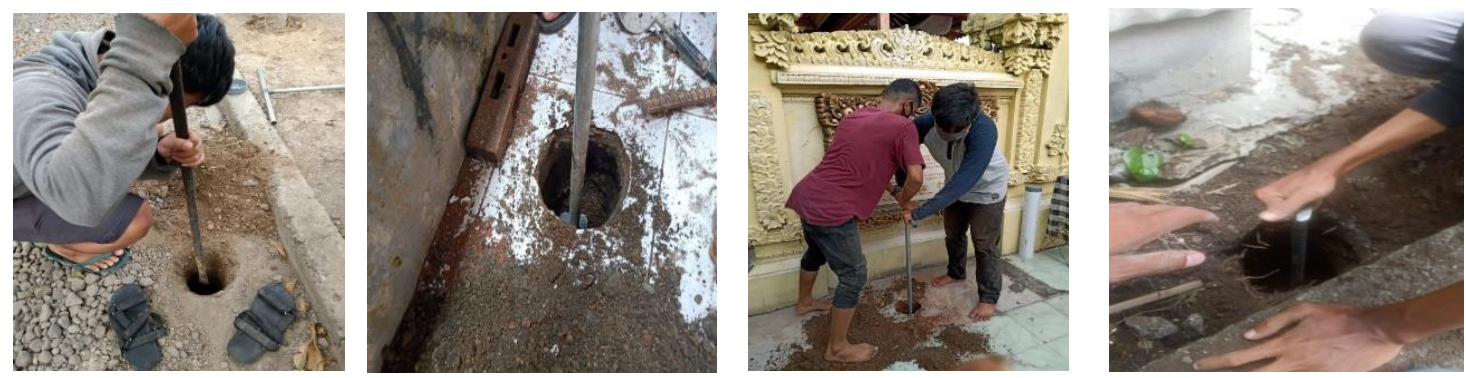

Gambar 6 Pembuatan lobang pipa biopori dengan bor tangan 
Sedangkan pada Gambar 7. merupakan hasil pemasangan pipa biopori yang sudah dilakukan di lokasi BTN Pengsong Indah
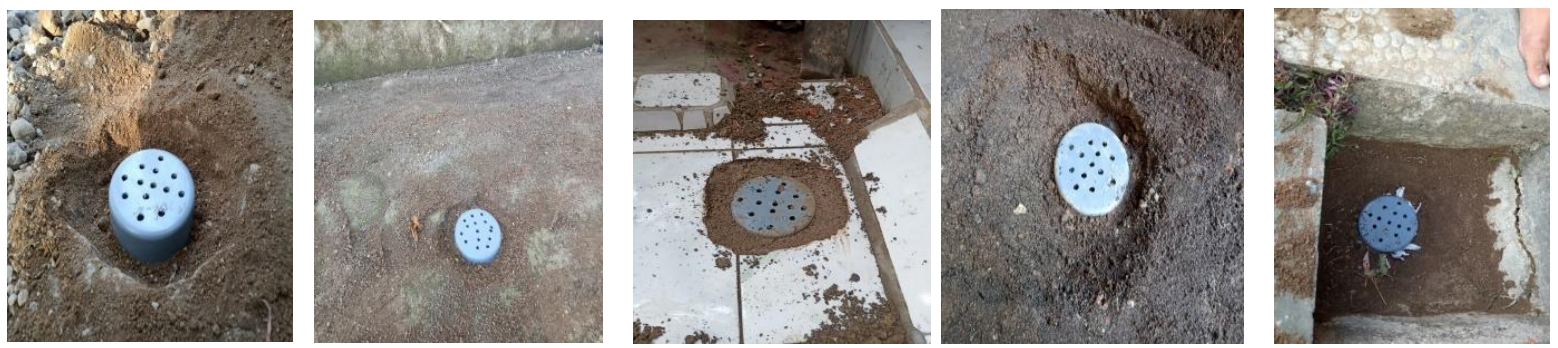

Gambar 7.Pemasangan pada halaman rumah dan bok saluran drainase

Berdasarkan patauan lapangan bahwa lokasi-lokasi yang rentan banyir saat hujan adalah lokasi yang lebih rendah dari permukaan jalan dan kondisi tersebut hampir merata di wilayah perumahan Pengsong Indah. Oleh karena itu contoh biopori dibangunan dibeberapa lokasi yang menyebar untuk dapat dijadikan conton oleh warga sekitarnya.

\section{Penyuluhan dan Diskusi}

Penyuluhan dalam ruang terbatas dilakukan untuk menyikapi permasalahan yang dihadapi dalam kondisi musim hujan, dan kaitannya dengan kiat mengatasi banjir dan pemanfaatan biopori sebagai salah satu alternatif dilingkungan perumahan warga BTN Pengsong Indah. Untuk menjawab semua pertanyaan yang pernah dilontarkan pada saat pemasangan media biopori maka dilakukan diskusi khusus yang membahas permasalahan tersebut dalam penyuluhan seperti Gambar 8
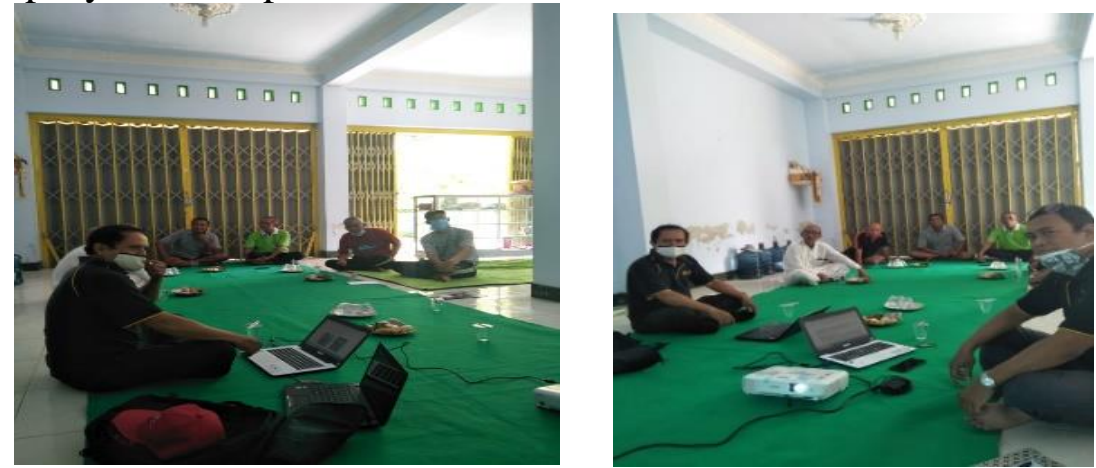

Gambar 8. Kegiatan penyuluhan tentang Biopori

Pemaparan masalah banjir yang mungkin terjadi sebagai ilustrasi disampaikan tim agar masyarakat sadar dengan kondisi topografi lokasi perumahan masing-masing yang rendah, sehingga dimusim hujan tetap waspada dan dapat bahu membahu melakukan perawatan drainase yang sudah ada agar tidak tersumbat. Banyaknya sampah disaluran, perlu dibersihkan warga sekitar agar aliran air hujan menjadi lancar terutama pada lokasi -lokasi pertemuan saluran drainase yang rawan banjir. Sampah organic dapat digunakan sebagai mengisi biopori untuk menghasilkan kompos pupuk organic bisa digunakan sebagai pupuk tanaman.

Setelah selesai pemaparan materi yang tertera dalam leaflet olet tim, maka dilanjutkan dengan tanyajawab dan diskusi. Pertanyaan dihimpun oleh tim penyuluhan dan dikelompokan sesuai jenisnya. Pertanyaan tentang saluran drainase yang selalu macet dan muka air tanah yang cepat naik saat hujan, menjadi bahasan menarik dalam diskusi ini seperti pada Gambar 9. 

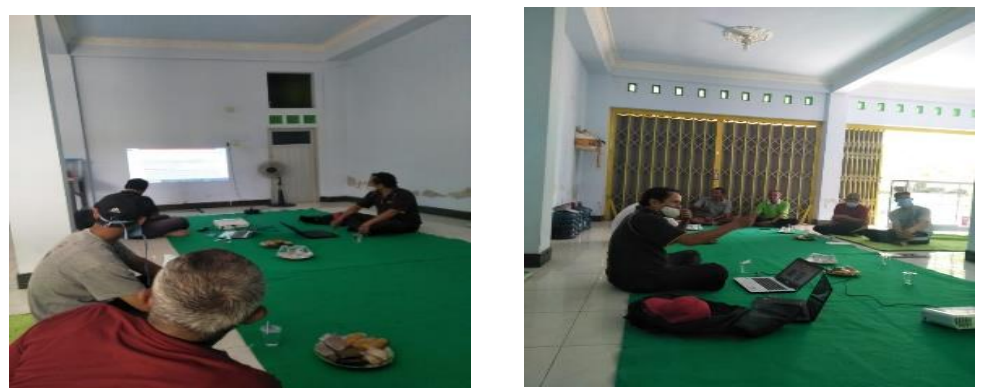

Gambar 9. Diskusi dan tanya jawab

Penyuluh memberikan saran agar warga sekitar saluran drainase selalu kontrol terhadap kondisi kebersihan saluran saat menjelang musim hujan. Ke dua warga harus proaktif melakukan perawatan saluran secara bergotong royong dan penggunaan sampah-sampah organik untuk pengisi biopori yang ada disekitarnya. Dengan cara tersebut diharapkan sebagai salah satu solusi cukup membantu dalam mereduksi banjir dan genangan disekitar perumahan warga.

\section{KESIMPULAN DAN SARAN}

Kesimpulan yang dapat diambil dari pelaksanaan pengabdian ini yakni peserta pengabdian telah mengetahui cara pembuat biopori dan dan pemasngannya, pemasangan biopori telah dilakukan pada 7 lokasi dikawasan BTN Pengsong Indah sebagai contoh dan pengabdian berjalan lancar. masyarakat sangat tertarik dengan materi saat penyuluhan. masyarakat telah mengetahui bahwa biopori dapat mereduksi genangan disekitar permukiman pada musim hujan.

\section{UCAPAN TERIMAKASIH}

Dengan telah selesainya pelaksanaan pengabdian dengan baik, ucapan terimakasih kami sampaikan kepada masyarakat, tokoh-tokoh masyarakat BTN Pengsong Indah dan LPPM UNRAM sehingga dapat ikut serta dalam semnas Pepadu 2020.

\section{DAFTAR PUSTAKA}

Jaya Negara I G . 2016. Analisis Kemampuan Peresapan Limpasan Hujan pada Model Embung Lahan Diagonal terhadap Gradasi Lapisan Tanah di Lahan Kering, Jurnal Spektrum Sipil, Vol 3 No2

Permanasari EE. 2018. Penyelamatan Air tanah dan Penanggulanagan Sampah dengan teknik Bio pori dan Komposter di Pemukiman Kecil Di keluaraman Ciputata dan Ciputat Timur. Jurnal JPKM, Vol.4, No.1, September 2018, Hal 51 - 64 , DOI: http://doi.org/10.22146/jpkm.33412 